\title{
Culture positivity for exact diagnosis of Pseudomonas aeruginosa endophthalmitis
}

\section{Positividade de cultura para o diagnóstico exato de endoftalmite por Pseudomonas aeruginosa}

Yakup Aksoy ${ }^{1}$, Yusuf Emrah Eyl ${ }^{2}$, Kadir Colakoglu $^{3}$, Emre Zorlu ${ }^{4}$, Fahri Gurkan Yesil $^{5}$

Dear Editor,

We read the article "An outbreak of forty five cases of Pseudomonas aeruginosa acute endophthalmitis after phacoemulsification" written by Guerra et al., with interest ${ }^{(1)}$. They described an outbreak of Pseudomonas aeruginosa endophthalmitis post cataract surgery and discussed clinical findings, treatment and outcomes. We thank to the authors for their lightening analysis and we would like to make some contributions.

Postoperative endophthalmitis is one of the most destroying complication of intraocular surgery. Pseudomonas aeruginosa is a Gram negative, non-fermentative bacteria which causes severe endophthalmitis, ulcerative keratitis which are more rapidly progressive and visual acuity outcomes is generally poor ${ }^{(2,3)}$. Pseudomonas aeruginosa also causes severe life-threatening diseases such as meningoencephalitis, endocarditis, pneumonia and sepsis. The treatment of endophtalmitis usually emprical at the begening. But the laboratorial diagnosis of the causative agent should always be pursued, in order to ensure a more specific treatment, to guide final therapeutic modifications and to prevent any visual impairment due to a wrong or delayed diagnosis $(4)$

In this article authors reported that forty-five patients were diagnosed as Pseudomonas aeruginosa but also they informed that cultures for pseudomonas were positive in only twenty-six patients. In nineteen patients cultures for Pseudomonas were negative. We believe that the culture positivity is a necessity for diagnosis of "Pseudomonas aeruginosa endophthalmitis" and in these nineteen culture negative patients the causative agent is not definite. Chen et al., reported a retrospective, noncomparative, consecutive case series of 71 patients and they had analysed medical records of patients only who had culture-proven P. aeruginosa endophthalmitis (2). Goldschmidt et al., suggested as an alternative method"the real timepolymerase chain reaction" in rapid pathogens diagnosis of bacterial endophthalmitis ${ }^{(5)}$. Culture positivity is not possible everytime in all samples for endophthalmitis, but using such kind of new methods may facilitate to find causative agent and reduce the number of patients with culture-negative.

We celebrate Guerra and friends for the presentation and offer our respects.

\section{REFERENCES}

1. Guerra RL, Freitas B de P, Parcero CM, Maia Júnior O de O, Marback RL. An outbreak of forty five cases of Pseudomonas aeruginosa acute endophthalmitis after phacoemulsification. Arq Bras Oftalmol. 2012;75(5):344-7.

2. Chen KJ, Sun MH, Lai CC, Wu WC, Chen TL, Kuo YH, et al. Endophthalmitis caused by Pseudomonas aeruginosa in Taiwan. Retina. 2011;31(6):1193-8.

3. Lipener C, Ribeiro AL. Úlcera de córnea bilateral por pseudomonas em usuário de lente de contato descartável. Arq Bras Oftalmol. 1999;62(6):747-9.

4. Uesuguı E, Cypel-Gomes MC, Atique D, Goulart DG, Gallucci FR, Nishiwaki-Dantas $M C$, et al. Identificação laboratorial dos patógenos oculares mais frequentes e sua suscetibilidade in vitro aos agentes antimicrobianos. Arq Bras Oftalmol. 2002;65(3): 339-42.

5. Goldschmidt P, Degorge S, Benallaoua D, Basli E, Batellier L, Boutboul S, et al. New test for the diagnosis of bacterial endophthalmitis. Br J Ophthalmol. 2009;93(8):1089-95.
Submitted for publication: May 27, 2013

Accepted for publication: May 29, 2013

1 Ophthalmology Department, Hakkari Military Hospital, Hakkari, Turkey.

2 Emergency Department Medicine, Hakkari Military Hospital, Hakkari, Turkey.

${ }^{3}$ Ophthalmology Department, Kasımpasa Military Hospital, Istanbul, Turkey.

${ }^{4}$ Neurosurgery Department, GATA Haydarpasa Education Hospital, Istanbul, Turkey.

${ }^{5}$ Cardiovascular Surgery Department, Gülhane Military Medical Academy, Ankara, Turkey.
Funding: No specific financial support was available for this study

Disclosure of potential conflicts of interest: Y.Aksoy, None; Y.E.Eyi, None; K.Colakoglu, None; E.Zorlu, None; F.G.Yesil, None.

Correspondence address: Yakup Aksoy. E-mail: dryakupaksoy@gmail.com

\section{Authors' reply}

\section{Resposta dos autores}

Ricardo luz leitão Guerra ${ }^{1}$, Bruno de Paula Freitas ${ }^{2}$, Cintia Maria Felix Medrado Parcero²; Otacílio de Oliveira Maia Júnior ${ }^{1}$; Roberto Lorens Marback ${ }^{3}$

Dear Editor,

We are pleased with the interest in our paper and appreciate the valuable comments that complements the presented article and provide usefull information. I would like to highlight one peculiarity of our presentation.
It is known that real-time polymerase chain reaction (PCR) has improved the diagnosis of bacterial endophthalmitis ${ }^{(1,2)}$, but conventional microbiology methods, such as culture, are routinely used for microorganisms laboratory characterization and the positivity range from $24 \%$ to $85 \%$ according to different studies ${ }^{(3)}$. 
Indeed cultures were not positive in all the presented cases. However, due to diagnostic method limitations and analyzing the clinical findings and uniform response to the treatment, as well as all patients had been operated in two consecutive days in a single center by the same surgeon, lead the authors to believe that is acceptable the presumptive diagnosis in cases that culture was not positive.

We thank to the authors for their commendation of our paper.

\section{REFERENCES}

1. Goldschmidt P, Degorge S, Benallaoua D, Basli E, Batellier L, Boutboul S, et al. New test for the diagnosis of bacterial endophthalmitis. Br J Ophthalmol. 2009;93(8):1089-95.

2. Bispo PJ, de Melo GB, Hofling-Lima AL, Pignatari AC. Detection and gram discrimination of bacterial pathogens from aqueous and vitreous humor using real-time PCR assays. Invest Ophthalmol Vis Sci [Internet]. 2011 [cited 2012 Jan 3];52(2):873-81. Available from: http://www.iovs.org/content/52/2/873.long

3. Bispo PJ, Melo GB, d'Azevedo PA, Höfling-Lima AL, Yu MC, Pignatari AC. [Culture proven bacterial endophthalmitis: a 6-year review]. Arq Bras Oftalmol. 2008;71(5):617-22. Portuguese.

${ }^{1}$ Physician, Department of Ophthalmology, Hospital São Rafael, Fundação Monte Tabor, Salvador (BA), Brazil.

2 Physician

${ }^{3}$ Professor, Department of Ophthalmology, Hospital São Rafael, Fundação Monte Tabor, Salvador

(BA), Brazil. 